\title{
THE INSTITUTE OF PERSONNEL MANAGEMENT
}

\begin{abstract}
A MANAGEMENT conference which, each year, attracts about 1,000 members from home and overseas must surely be a source of considerable attraction. Each year the conference of the Institute of Personnel Management attracts about one-fifth of its members, and the question could fairly be asked about the nature of the attraction. While the good fellowship would draw many to the conference, there is little doubt that the quality of speakers and the relevance of their subject-matter is the main draw. The content of the sectional meetings over the past five years could, indeed, well be compounded to form a useful 'Students' Refresher Guide to the Intricacies of Industrial Relations in Britain'.
\end{abstract}

This year's conference at Harrogate was held during October 4-6, and was no exception to the general rule. P. M. Uri, director of Lehman Bros., Paris, discussed the role of planning in economic growth and showed that, in those countries where there has been most rapid rate of growth-the U.S.S.R., Japan, Germany, Italy and France-the only truly common denominator has been a surplus of manpower. Planning has been carried out in different ways in different countries, with each one initiating new forms of long-term finance. In France, the planning organization is made up of a Commissariat Du Plan, consisting of three or four people supported by another small group of individuals who act as secretaries for different industrial committees. Apart from this small staff, there are about one or two thousand people around the small nucleus. They are organized in a certain number of committees by industries, plus an overall economic committee which is trying to see what kind of balance can be achieved between total investment, total resources and total sources of finance. The constitution of these committees is partly people from industry, partly people from the administration, partly independent experts, and partly members of the trade unions. This is considered the mainspring of democratic planning and how a plan can bo implemented. Such a form of planning has played an important political part, because it has helped to create a conviction about important decisions which had to be reached on the morrow of the liberation. That was a time of utter economic destruction, and two hard decisions had to be reached. One was that the limitation of the working week to forty hours had to be abandoned, and the workers had to be prepared to work longer hours to speed up reconstruction. Tho second decision was to postpone reconstruction for housing purposes and give priority to the productive equipment of the country. Now the plan may play a different part.

Dr. N. W. D. Beese, works relations officer, Billingham, Imperial Chemical Industries, Ltd., examined the place of employee communications in the building up of good industrial relations. These have to be related to other forms of communication in industrial organizations. They are the day-to-day line management flow of information necessary for the operation of the organization and the exchange of information in joint consultative procedures such as works councils and efficiency committces. The line managemont and joint consultative channels of communication are first pricrities and only when these have been properly organized and are working smoothly is it feasiblo to embark on an employee information service programme.

At a sectional meeting, some of the ramifications of the so-called wages drift were examined. This is probably a more important cause of inflation than increases in wages which are negotiated nationally. The drift occurs at factory- and office-level when earnings are increased by over-time, various kinds of incentive schemes and fringe benefits. According to K. J. Burton, formerly secretary of the British Employers' Confederation, wages drift is due to the fact that there are no appreciable unused reserves of labour, while there is insidious danger in the failure to recognize that the significance of basic wage-rates as the determinant of earnings and of total labour costs ranges considerably from industry to industry. False comparisons are often made during essential stages in collective bargaining. The remedy is not to weaken collective bargaining arrangements but to aim at greater co-ordination of variations within industries and localities.

Investigations by Dr. M. Jahoda, Nuffield Research Fellow at the Brunel College of Technology, into the relations between industry and technical colleges, showed that, while collaboration between industry and college functions by and large is in a satisfactory manner, there is also a number of general problems. The Hives Council's stipulation, for example, that responsibility be shared between colleges and industry permits in practice a variety of interpretations.

Since, from a company's point of view, education leading to a diploma in technology is expensive (the cost of one student for four years is estimated to be about $£ 2,000$ ), some companies feel that they carry, or should carry, major responsibility, certainly for the industrial periods. Where this view is also held by a college, divided responsibility alternating every six months between college and company is the inevitable consequence. Colleges cannot choose this interpretation, even if they wished to, because the diploma in technology is essentially an academic qualification; the Hives Council holds the college responsible for attesting that a student's industrial training has been adequate. This means that the college must exercise its responsibility in shaping the industrial training periods, preferably by joint agreement on their nature and content before a student begins his training. Shared responsibility is most easily achieved in student selection, which must find the approval of both partners; it is most difficult in arranging the actual practical work of the student.

A further difficulty arises from the fact that by far the most promising technique for integrating practical and theoretical knowledge in the student's mind is the tutorial system. Here, college staff visit the student at his place of work to discuss with him the manner in which his practical experience rolates to his academic knowledge. There is still some confusion about the function of the college tutor, both among tutors and in industry. While visits to firms can serve public relations purposes, provide consultation opportunities on technical matters for the company or the tutor, or preferably both, the major object of these visits is to help individual students in achieving integrated knowledge. In the light of experience, the hope of achicving integration by arranging industrial 
work so that it is an immediate application of what the preceding college period presented theoretically must be regarded as naive and impractical. The task of integration is made easier where companies appoint industrial tutors to students working for a diploma in technology, who remain a constant focus for immediate technical supervisors.

Jahoda had asked students how they liked their first industrial training period and how much they had learned from it. A combination of answers provides some yardstick for evaluating industrial training. By this yardstick, 64 per cent of students engaged in project work felt they had a good experience; 54 per cent in training schools, 38 per cent working on a technician-level, 31 per cent on a perambulatory course, and 18 per cent on a production worker-level valued the industrial period highly. In spite of the subjective nature of the judgment, these figures indicate some aspects of a successful industrial training period.

The question whether a personnel manager should advise general management on matters of organization structure and the style of operational management was examined by W. G. McClelland, Research Fellow in management studies at Balliol College, Oxford. MeClelland indicated that the personnel manager has the responsibility of supplying satisfactory personnel, and, properly to diseharge this responsibility, he must be able to analyse what they will be called on to do and what they will get out of it, and to make recommendations designed to ensure that the organization can compete successfully in the labour market. Since requirements and rewards are not merely matters of skill and pay, but are affected by organization structure and style of management, the case for the personnel manager's right to intervene would seem easy to establish. In the case of managerial personnel, most selection consultants insist on analysing the organization before embarking on recruitment and selection.

The personnel manager may also be called on to devise and apply tools of management-such as appraisal forms and training in communications techniques-required as the expression of an inappropriate management philosophy or to combat the consequences of an ineffective organization structure. He may be called on to deal with individuals cracking under the strain of an impossible situation, and may well feel that he would be better engaged as a public health officer devising means of prevention than a physician attempting cure.

On the other hand, he is at present ill-equipped to advise on these matters. How many personnel managers, to take the simplest example, would be prepared to say what span of control in a particular hierarchical organization minimized the sum of the disadvantages of too little attention to immediate subordinates on one hand, and too many steps between bottom and top on the other? From his safe haven of aptitude tests of proved reliability and validity, and accurately pin-pointed learning curves, the personnel manager steps here into a largely uncharted world in which line managers can-and certainly will-argue with him.

Better use of human resources was discussed by a research psychologist and a personnel director. Dr. J. Hopkins, of the National Institute of Industrial Psychology, suggested that any task can be made to vary in at least three ways: duration, scope of action and responsibility. Any of these variables can be increased or reduced and job enlargement can result when they are increased in ways which succeed in strengthening the meaningfulness, although there might be considerable increase in duration, scope or responsibility. It should, however, be considered how far job enlargement might be psychologically desirable. Evidence of people's reactions to their jobs is still scanty and anecdotal. Attitude surveys and similar types of inquiry have shown that highly repetitive and subdivided tasks - the opposite of job-enlarged tasks - are apparently almost as congenial to some people as they are abhorrent to others. Whatever the variety of people's comments about work, they consistently reveal preoccupations with only a comparatively limited number of themes. Among the most frequent are the pace of the job, the security or insecurity engendered by it, its variety, its inherent creativeness, its difficulty and its sociability. These themes indicate a response to at least three identifiable aspects of work: the amount of constraint the task imposes, the 'completeness' which it allows one to experience, and the degree of personal involvement which it demands. The status or value of an enlarged job as against a more subdivided one should be viewed in relation to these aspects of work. T. G. P. Rogers, of I.B.M., United Kingdom, Ltd., is in no doubt that Britain has not fully developed its human resources, and quoted an example from I.B.M. in the United States to show what can be done. Much of that Company's work has changed from electro-mechanical to electronic engineering. Redundancy is anathema to the Company. It had to make electronics technicians out of machinists and assemblers. They had to be taught algebra, electrical and electronic theory, and computer theory as a prelude to their practical training and their subsequent employment on final test operations on computer manufacturing. This was done in such a way as to enable the American management to conclude that a substantial percentage of what are called semi-skilled operators are capable of this change, regardless of their age.

The important factors are-good selection in assessing mental ability, aptitude, and motivation, and thorough full-time class-room and workshop training. What is required in British industry is a new attitude in management towards operator training-skills should be taught and not bought; and also in many cases a new shop-floor attitude-more self-confidence and loss rigidity of outlook.

The two final speakers were asked to look at industrial relations in the future. One, Mr. Frank Cousins, general secretary of the Transport and General Workers' Union, expressed the strong opinion that the basis of all industrial troubles is insecurity and that economic planning will not be possible until there is a new approach to industrial relations. Trade unions want to be consulted about more than the incidence of redundancy, and which men will go. They wish to talk about the basic reasons for redund. ancy and whether the workers have any place in determining the policies which cause or do not cause this redundancy to arise. There is, also, far too much tendency to accept that "if a firm or a trado union has bright ideas about the future of industrial relations, it sounds nice but you cannot do it unless you can persuade everybody to do it first; you cannot, in fact, wait for the slowest". Other viows put forward by Cousins were that "if we regard industrial relations as a steady process of agreement on consultation through operating an agreed but flexible structure, we have still failod", and that 
"we will not resolve tho problems if wo think we have a common purpose. We have two different purposes. We have to see how we are going to serve them and how to bring the consequent results together at some stage. We do not start off from the basic level. This could be one of the most significant contributions to economic planning, if we first accept that principle".

The other, Sir Roy Harrod, Nuffield reader in international economics in the University of Oxford, discussed the relations of economic planning and incomes policy. For a number of years aftor the Second World War inflationary tendencies were certainly due to "too much money ehasing too few goods", and the right way to correct this situation was by monetary and fiscal policies. In more recent times it has appeared, both in Britain and in the United States, that there might be a tendency to inflation, in the sense of rising prices, even in periods when it was perfectly clear that the monetary demand for goods and services was not excessive, as made evident, for examplo, by the economy being slack or depressed. It seemed inescapable that a rise in prices might occur simply because increases of wages, salaries, otc., were being granted in excess of any increase in national productivity and give rise to 'cost-push' inflation.

In the recent period people have become selfconscious about the fact that, in the past seven years, Britain has shown a low growth-rate. The same is also truo of the United States. If Britain is to make a change in her monetary and fiscal policies and try to achieve the growth-rate of which the country is capable, this brings into the forefront the question of how to prevent inflation of the kind that is caused by a 'cost-push'. There is the possibility that a policy of full growth will tend to accelerate claims for higher pay and make employers, who, under a growth policy, will be enjoying good profits, roadier to give them. Hence the idea of a National Incomes Commission.
Tho idea of a policy of planning for economic growth entails problems of formidable dimensions. Such a policy cannot be implomentod without goodwill on the labour side, and to get labour goodwill it will be needful to show that there is some method to secure restraint on the side of distributions of dividend also. But within the field of wages itself there are vast problems. There is the question of relation of wage increases to productivity increases, the question. of the 'wages drift', the question of differentials between grades and between occupations, the proper function of wage increases in relation to the mobility of labour as betweon rising and doclining industries, the problem of leap-frogging, the question of how a trade union leader can relate his thoughts to a national policy without sacrificing, or seeming to sacrifice, the interests of the particular group of workers which he is appointed to look after.

All these interconnected questions have to be looked at in an impartial way without prejudice. Public opinion in certain quarters has been too much inclined to suppose that labour is always to blame when overall wage increases have boon excossive, without appreciating the complexity of the problem. On its side, labour may not always understand the relation between excessive wage increases and inflation. The idea of looking at this complex of problems in a systematic and impartial way presents a great challenge.

In his presidential address to the conference, $\mathrm{Mr}$. Gerald Moxon of United Glass, Ltd., reminded members that the Institute would be celebrating its jubilee in 1963. Its influence over many years in building up good industrial relations deserves to be much more widely known and it is to be hoped that suitable opportunities will present themselves in the coming yoar. It is so long since the Institute appealed for money to extend its activities that the Jubilee Appeal should meet with considerable response.
T. H. Hawkrns

\section{BONE MARROW THERAPY AND CHEMICAL PROTECTION IN IRRADIATED PRIMATES}

\begin{abstract}
$\mathrm{D}^{\mathrm{t}}$ URTNG August 15-18 an international symposium on "Bone Marrow Therapy and Chemical Protection in Irradiated Primates" was held in Rijswijk, the Netherlands. The symposium was sponsored by the Organization for Health Rosoarch of the Central Organization for Applied Scientific Research in the Netherlands (T.N.O.), and the Radiobiological Institute T.N.O. acted as host for the meetings. Thoro were 32 participants from France, the Netherlands, the United Kingdom and the Unitod States, of whom 22 presented papers. The main object of tho symposium was to exohange ideas as to the causes of difficultios in tho treatmont of irradiated primates, including human patients, and to discuss future rosoarch plans to overcome these difficulties.

In the session on "Bone Marrow Transplantation in Monkeys", C. Ambrus (Roswell Park Memorial Institute, Buffalo) presonted data on homologous and autologous bone marrow transplantation in rhosus monkeys. Autologous transplantation gave better survival than homologous, but a high percentage of
\end{abstract}

the homologous-treated animals survivod for as long as 24 months with evidence of secondary disease in only one animal. The data showed that there was a marked tendency toward reversal of the chimæric stato in tho homologous-treated monkeys.

R. J. Young (Radiobiological Laboratory, Austin, Texas) reported the results of homologous and autologous transplantation in twenty rhesus monkeys. Autologous transplantation afforded good survival, but there were no long-term homologous survivors. The data showed evidence of secondary disease in homologous animals in which the take of the graft was ascertained by red cell antigens.

The data presented by Mrs. F. Nowsome (University of Tennessee Medical Units, Memphis) showod evidence that homologous marrow after $550 \mathrm{r}$ was more effective $48 \mathrm{~h}$ after irradiation than at $30 \mathrm{~h}$. She reported on heterologous transplants using oynomolgus donors and rhesus recipients with the electrophoretio patterns of hæmoglobin serving as an indication of the take. She concluded that the grafts took but were later rejected. The same results wore 